\title{
The Mickey Mouse Kachina and Other "Double Objects": Hybridity in the Material Culture of Colonial Encounters
}

\section{Citation}

Liebmann, Matthew. 2015. The Mickey Mouse kachina and other "Double Objects": The hybridity in the material culture of colonial encounters. Journal of Social Archaeology 15 (3): 319-341.

\section{Published Version}

doi:10.1177/1469605315574792

\section{Permanent link}

http://nrs.harvard.edu/urn-3:HUL.InstRepos:14105804

\section{Terms of Use}

This article was downloaded from Harvard University's DASH repository, and is made available under the terms and conditions applicable to Open Access Policy Articles, as set forth at http:// nrs.harvard.edu/urn-3:HUL.InstRepos:dash.current.terms-of-use\#OAP

\section{Share Your Story}

The Harvard community has made this article openly available. Please share how this access benefits you. Submit a story.

Accessibility 
Corresponding Author:

Matthew Liebmann, Harvard University, 11 Divinity Ave, Cambridge MA 02138 USA

Email:Liebmann@fas.harvard.edu

Title: The Mickey Mouse Kachina and Other "Double Objects": Hybridity in the Material Gulture of Golonial Encounters

Author:

Matthew Liebmann

John and Ruth Hazel Associate Professor of the Social Sciences

Department of Anthropology

Harvard University, Cambridge, MA

\begin{abstract}
:
Hybridity is a term used by anthropologists to characterize the amalgamation of influences from two (or more) different cultural groups. Hybridity has captivated archaeology in recent years, especially archaeologists investigating colonialism in Native American contexts. At the same time, a growing chorus of critics has begun to question anthropology's devotion to hybridity and hybrid objects. These critics take issue with the term's alleged Eurocentrism, implications of cultural purity, and evolutionary etymology. In this article I address these critiques and advocate a more circumscribed use of hybridity in archaeology. I caution against the abandonment of the term entirely, because the archaeological identification of hybridity provides insights into both present-day (etic) and past (emic) perspectives on cultural amalgamation. Hybridity reveals the biases of contemporary researchers regarding the societies we study, as well as highlighting the ways in which power structures centered and marginalized colonial subjects in the past. To illustrate these points I draw on case studies involving the Hopi Mickey Mouse kachina, eighteenth- and nineteenth-century Indigenous-colonial whips from the American Plains and southeast Australia, and seventeenth-century Pueblo ceramics from the American Southwest.
\end{abstract}

Keywords: hybridity $\bullet$ archaeology $\bullet$ postcolonialism $\bullet$ ceramics $\bullet$ American Southwest $\bullet$ archaeology of colonialism $\bullet$ Ancestral Pueblo 
Imagine you are a tourist visiting the Hopi mesas in the early 1950s. You spend a sunburned day at one of the sandstone villages. There you squint at the kachinas as they dance in the plaza (or more properly to the Hopis, katsinam, masked beings that act as messengers between the human and spirit worlds). If you're lucky, maybe you are invited into a Hopi home to fill your belly with mutton stew and piki bread. At the end of the day you start down the path that leads to the base of the mesa, and to the station wagon that will carry you and your family off to the Grand Canyon. But before you leave, you stop by the side of the steep dirt road to buy a souvenir - maybe some handmade pottery, or a piece of turquoise jewelry. Or maybe you purchase a kachina doll (tithu), a carved cottonwood statue of one of the dancers you saw in the plaza that day. Most likely you would reach for a "traditional" doll- a dancer with the head of an eagle or a bear or an owl. But you might also spot a more familiar figure among the masked sculptures that would cause you to pause and chuckle. There with the butterfly maidens, kokpellis, and ogre kachinas you may have seen Mickey Mouse, complete with his telltale round black ears, holding a gourd rattle and wearing a traditional cotton kilt and moccasins [FIG. 1]. Anthropologists often classify objects like Mickey Mouse kachina dolls as hybrid material culture - things whose parts originate in two different worlds. The histories of two cultures tangle within these hybrid things, leading Philip Jones (2007:12) to label them "double objects." In the case of the Mickey Mouse kachina, traditional Hopi culture fuses with an icon of modern corporate entertainment. The disparate worlds of colonizer and Indigenous are mashed together in a single artifact, a seemingly archetypal example of cultural hybridity.

Yet these dolls were not created solely for tourists, nor as objects of whimsy or kitsch. When Mickey Mouse began appearing on the silver screen in the early twentieth century, Hopi people associated the cartoon character with classic stories about Tusan Homichi, a legendary 
mouse who defended the Hopi people by battling a chicken-stealing hawk (Kennard et al. 1944). Not long after, the Mickey Mouse kachina began appearing in the plazas of Hopiland. He danced as an actual Mudhead kachina from the 1930s-50s, alongside the "traditional" kachinas that had been dancing there for centuries (Green 1991:208). Mickey's playful persona fit the roles performed by Mudhead clowns perfectly, acting the fool and engaging the audience in games.

Situated in this context, we might wonder what the label hybrid says about Mickey Mouse kachina dolls. Does calling these double objects hybrids enlighten us about their social roles, or obfuscate them? Did the Hopi carvers who made these dolls recognize them as a fusion of Hopi and non-Hopi culture? Or was Mickey integrated more or less seamlessly into the Hopi world as a manifestation of Tusan Homichi? If we choose to identify these dolls as a product of hybridity, to whom are we saying they are hybrids? To the tourists of the 1950s who purchased them? To the Hopis of the 1950s who danced as Mickey the Mudhead? To contemporary anthropologists? Indiscriminately labeling objects as "hybrids" risks projecting our own understandings onto the societies we study, telling us little about the perspectives of the people who made and used these objects. In other words, by choosing to call some things "hybrid" (and others not) we reveal our own preconceptions about the anthropological Others under consideration. Hybridity, it seems, is in the eye of the beholder.

Twenty-first century anthropologists are no more immune to the allure of double objects than were the collectors who first snatched up Mickey Mouse kachina dolls six decades ago. On the contrary, hybridity continues to fascinate contemporary scholars, particularly the cultural mashups that occur in colonial contexts. Today, the study of social mixture is a mainstay of cultural analysis (Palmié 2013a:464), and the allure of hybridity seems to increase with the passing of each annual conference. Mixing, melding, fusing, and blending cover the pages of 
Current Anthropology, American Anthropologist, and countless edited volumes (Stockhammer 2012;

Card 2013; Palmié 2013a; VanValkenburgh 2013:310). Wary of outdated and unrealistic desires for authentic, pure, and clearly identifiable "traditional cultures," anthropologists today embrace hybrids as good(s) to think with, to paraphrase Claude Levi-Strauss (1963).

Over the past century, anthropologists have borrowed and coined a plethora of terms to characterize the combination of preexisting cultural forms to create something new:

acculturation, syncretism, bricolage, creolization, and entanglement have all garnered great attention and strong criticism (see Liebmann 2013:43). But the term hybridity has stormed onto the anthropological scene more recently as one of the favored Anglophone terms to refer to the blends of culture marking "our mongrel selves" (Rushdie 1991:394). Inspired by the writings of postcolonial scholars such as Homi Bhabha (1994), Stuart Hall (1990), and Robert Young (1995), studies of hybridity have proliferated particularly in archaeology of late (Van Valkenburgh 2013:310). Nowhere is the fascination with inter-cultural mixture more apparent than the study of colonial encounters, where attention to "hybrid" things has gained particular traction (e.g. Card 2013; Liebmann 2008; Loren 2013; Stockhammer 2012; van Dommelen 2005, 2011; van Dommelen and Rowlands 2012; Van Valkenburgh 2013; Wu 2013).

Archaeologists today seem to find hybridity everywhere, and therein lays the problem. While we are quick to identify and deploy hybridity, archaeologists have been much slower to critically analyze the implications of this term and its theoretical baggage (Deagan 2013; Silliman 2013). In recent years, growing numbers of critics have questioned the utility of the term hybridity for anthropology and archaeology (Palmié 2013a \& b; Dietler 2010:52-53; Dawdy 2008:6; Silliman 2013; Stockhammer 2013). Like a kettle of vultures circling a wounded calf, these skeptics appear to signal hybridity's imminent demise. Thus archaeology stands at a crossroads in relation to hybridity. Should we abandon the concept, finding other means to describe the 
creation of new objects through recombination? Or can archaeologists reclaim it from the midden of anthropological theory? Does hybridity make a meaningful contribution, or is it just another term in a long list of jargon (and according to some critics, an ill-considered term at that [see Liebmann 2013])? What does hybridity imply, both deliberately and unintentionally? Why do objects thought to be "hybrid" - particularly those in Indigenous contexts - continue to enthrall (non-Native) audiences? What role does time play in the process of hybridization? That is, as Silliman (2013) and Palmié (2013a) ask, when does hybridity begin and end? And why do we label some objects hybrid, yet ignore the complex multi-cultural biographies of others?

\section{Defining Hybridity}

While uses of hybridity and hybridization vary considerably in recent archaeological literature, the term itself is often left undefined. So here I offer an explicit definition: cultural hybridity refers to the combination and modification of elements from two or more different social groups in ways that challenge preexisting power relations. Admittedly, this is a dense definition with many subtleties to parse. Note that hybridity is not a quality that inheres in objects themselves, nor does it exist independently in the world. Hybridity (or more properly, hybridization) is a practice, not an end point, and for this reason it is always unresolved and ongoing. To paraphrase Carolyn Dean and Dana Leibsohn (2003:6), hybridity is not so much the result of an "us" meeting a "them," but rather the process of creating an "us" and a "them." Note too that hybridity involves the mixture of cultural differences but not necessarily pure entities (contra Palmíe 2013a:464). Furthermore, hybridity invokes not the mere combination of preexisting elements, but their transformation to produce a whole that is more than the sum of its antecedent parts. Finally, hybridity emphasizes the challenges to power inherent in instances of 
cultural combination in ways not addressed by concepts such as syncretism, creolization, and entanglement.

Hybridity does not connote benign and innocuous combinations for postcolonial scholars. Rather, it often implies disruption and a forcing together of unlike things (Young 1995:26). In this way hybridity exposes the disjunctions as well as conjunctions that emerge out of colonial encounters (Kapchan and Strong 1999:249). More specifically, hybridity involves the relocation of power that accompanies any negotiation of cultural differences. In the words of Homi Bhabha: hybridization is not some happy, consensual mix of diverse cultures; it is the strategic, translational transfer of tone, value, signification, and position- - a transfer of power ... that changes the very terms of interpretation and institutionalization, opening up contesting, opposing, innovative, "other" grounds of subject and object formation. (Bhabha quoted in Seshadri-Crooks 2000:370) Hybridity, then, is not just another synonym for generalized cultural blending. For one thing, it implies a re-working of previously existing elements rather than any simple combination of two (or more) distinct cultural forms (Bhabha 1994:110). This transformation often challenges presumptive norms - assumptions about what is Indigenous and what is colonial, for example. It also underscores the potentially empowering nature of these double objects, which can both foster anti-colonial resistance and reinforce colonial domination by challenging binary categories such as Native American/European and traditional/modern. Hybridity has the ability to shock, transform, and revitalize social life, and in doing so it emphasizes the capillary actions of colonial power, drawing attention to the ways in which foreigners can colonize even the most "traditional" of Indigenous forms.

This emphasis on power and hybridity can be traced through Bhabha's writings back to the linguistic work of Mikhail Bakhtin (1981:358-61), whose foundational use of the term hybridity 
stressed the unsettling and transfiguring capacity of these new cultural formations. Bakhtin differentiates between two main types: organic (or unconscious) hybridity and conscious, intentional hybrids. Organic hybridity is the unintentional blending that occurs as a natural part of transcultural interactions. Organic hybrids are not produced deliberately, but emerge out of normal day-to-day interactions (in the realm of Bourdieu's doxa [1977:164-69]). Organic hybrids are the more common of the two types, occurring anywhere and everywhere that cultural interaction takes place. In this way, Bahktin’s organic hybridity closely resembles contemporary anthropological notions of entanglement (Thomas 1991, 1994; Hodder 2012)-independent from agency, organic hybridity "just happens" during cultural interactions. On the other end of the spectrum, intentional hybrids can also turn into unconscious hybrids over time (and back again). When double objects pass from the realm of discourse into the realm of things unspoken, they move from intentional to unconscious hybridity.

While organic hybridity is "commonplace and pervasive," intentional hybrids have the potential to be "powerfully interruptive" (Werbner 1997:1). In theory hybridity is everywhere and virtually all objects are hybrids (Silliman 2013:489). But blindly repeating aphorisms like "every culture is a hybrid," or "nonhybrids exist nowhere" hardly enlightens our understandings of complex cultural interactions (Kraidy 2005:vi; Johnson 2013 :477). For me, Bahktin's key distinction between organic and intentional hybrids ultimately rescues hybridity from the theoretical scrap pile. While organic hybridity may lead archaeologists to theoretical dead ends because of its ubiquity, the notion of intentional hybridity teems with potential to enlighten archaeologies of colonialism, because it throws the power dynamics of transcultural relations into high relief.

The identification of hybridity is fundamentally an exercise in taxonomy. Why do we choose to call some objects hybrid and not others? How do we classify double objects? Maybe 
more importantly, when do we consider something hybrid, and when not? When archaeologists talk about hybridity we are typically talking about production. Labeling something "hybrid" speaks to its origins. But hybridity is distinct from the appropriation of alien things. The consumption of foreign objects (Mullins 2011; Silliman and Witt 2010 ), while a fascinating phenomenon in its own right, is separate from the amalgamation of different things. Although an object may be utilized and appropriated by different social groups throughout its life, an intercultural biography does not constitute hybridity in and of itself. So, for example, the unmodified copper kettles that Native Americans obtained through trade in sixteenth- and seventeenth-century New France (Turgeon 1997; Howey 2011) are not what I would label hybrids. But the copper shields ("Coppers") famously potlatched among nineteenth-century tribes of the Pacific Northwest, which were transformed out of copper salvaged from the hulls of European and Asian ships, could be (Jopling 1989).

\section{Almost a Good Idea? Critiques of Hybridity}

The concept of hybridity has drawn its fair share of detractors. Nicholas Thomas calls hybridity "almost a good idea, but not quite" (1996:9). Criticized as going both too far (Dawdy 2008:6) and not far enough (Palmié 2013a:464), as powerfully disruptive (Ackermann 2012:12) and at the same time commonplace and pervasive (Werbner 1997:1), hybridity seems to be all things to all people. Even so, these critics echo a suite of common complaints (see Thomas 1996; Dawdy 2008; Dietler 2010; Palmié 2013 a \& b; Silliman 2013). They eschew hybridity because of its biological and evolutionary overtones; its Eurocentric application; its untenable assumption of preexisting cultural purity; and its lack of temporal specificity.

Condemnations of hybridity often start with its origins. The roots of hybridity stretch back to the Latin word hibrida, denoting the offspring of a tame sow and a wild boar. Citizens of 
the Roman Empire applied the same term to the child of a freeman and a slave. From its beginnings, then, hybridity conjured visions of domesticated civilization uniting with wild savagery. The term retained its checkered history through the nineteenth century, when eugenicists pointed to weak and sterile hybrids in support of the notion that pure racial types were superior and not to be mixed (Young 1995:6-19). In contemporary archaeology, Michael Dietler (2010:52) notes his discomfort with hybridity's application of biological metaphors to cultural processes (and racist metaphors at that).

However, to reject hybridity because of its etymology misses much of the point. It's true that the term is rooted in racist and evolutionary schemas. But like many other words, hybridity has been coopted and reinvested with new and different connotations over the past century. As linguists constantly remind us, the meanings of words are not fixed, and over time the meaning of hybridity has been driven into new furrows (Capone 2013:474). In fact, one of the signal contributions of postcolonial scholars is their recognition of subalterns' ability to appropriate and re-deploy signs of the colonizer to fit their own needs, in a manner analogous to anthropologists' co-opting of hybridity (Spivak 1990:228; see Liebmann 2012:138). Furthermore, Dietler's objection to hybridity's roots as a biological metaphor mischaracterizes the core of the issue. Hybridity has always concerned itself with classification and typology more generally, not only in the biological realm. While it was applied to biology early on, hybridity is not essentially biological. As Palmié's (2013a:466-67) exposition of dog breeding demonstrates, all claims of hybridity are cultural (try as they might to fix biology in place). It's not that hybridity exists in the natural world and is being appropriated as a metaphor for cultural mixture. Hybridity is, always and everywhere, a cultural concept - a taxonomic lens - through which the world is interpreted. 
This is not to deny the evolutionary limpets that cling to hybridity. Nineteenth-century notions of civilization and savagery still haunt identifications of hybridity today. This latent evolutionary thinking is one of the reasons critics castigate hybridity as Eurocentric.

Archaeological studies are guilty of employing hybridity freely to characterize material culture used by Indigenous peoples, but far less frequently to characterize that used by colonists (Jones 2007:11). Anthropologists have leveled the same "one-way" critique at the concepts of acculturation, syncretism, bricolage, and creolization, and this may in fact prove to be a hurdle that hybridity is similarly unable to overcome. By placing the focus squarely on Indigenous interactions with colonial powers, applications of hybridity emphasize post-1492 encounters as the most significant events in much longer Indigenous histories. However, these problems do not inhere in the notion of hybridity. Instead, they stem from contemporary archaeological applications of the concept. In theory, hybridity applies just as much to the "composite" material culture of the colonizer as that of the colonized, and to pre-Columbian contexts as well as those that occurred after the voyage of the Niña, the Pinta, and the Santa Maria. The only way to address this unequal application is for archaeologists to heed hybridity on the other side(s) of the colonial encounter as well, in contexts where power dynamics favor colonial settlers.

But the most strident critique of hybridity contends that it relies on an untenable notion of pre-existing cultural purity (Dawdy 2008:6; Gilroy 2000:251; Hutnyk 2005:81-82; Palmié 2013a \& b; Silliman 2013:491). How can you have a mixture of anything without the assumption of pure entities beforehand? Without question, anthropologists find the mere suggestion of pure cultures problematic (Palmié 2013a:464). Anthropology has proven over and over again that notions of bounded, homogenous, monolithic cultural entities - what Eric Wolf termed the billiard ball approach to culture — do not correspond to ethnographic realities (Barth 1969; Wolf 1982:6). Cultures cannot be packaged in a box and set neatly apart from one 
another on the anthropological shelf. As Nicolas Thomas (1996:9) notes, in an age of ethnic cleansing, fervent religious fundamentalism, and a world scarred by nationalism, arguments about culture that deny the possibility of purity seem ethically and politically urgent. In other words, anthropologists have embraced the virtues of cultural mixing and ambiguity precisely because notions of cultural purity are so problematic. But if hybridity depends on notions of cultural purity, most anthropologists would understandably say "count me out."

I agree that any notion of pure cultural essences is problematic and ontologically untenable. However, hybridity is about the difference of things in relation to one another, not about purity in isolation. Thus the concept of cultural hybridity does not necessarily rely on notions of antecedent purity. Rather, hybridity assumes only preexisting cultural difference. The distinction is significant. While I would have a hard time defending any notion that cultural purity has existed anywhere in the world, cultural differences do exist. If cultural hybridity results from the combination (and modification) of unlike things, then the conditions that promote hybridity are simply the coming together of different people, things, and ideas. And colonial contexts are quintessential crucibles in which different people, different things, and different ideas are mixed.

But hybridity is not something we should be content to simply identify - merely labeling one artifact as hybrid and another as unalloyed. As Clifford Geertz notes, as anthropologists "we are attempting to articulate a way of looking at the world, not to describe an usual object" (Micheelsen 2000:11). For archaeologists, that means we can use hybridity to better understand the ways in which people may have viewed double objects in the past and the roles they may have played in past social worlds. We can also use hybridity to better understand the ways in which we (in the present) view the people behind those objects. 
As Geertz further opined, there can be no ascent to truth without a descent to cases (1968:22). In that spirit I now turn to an archaeological study of hybrid objects. I choose the cases that follow specifically to illustrate the convictions borne out in the previous paragraphs: that hybridity has the potential to tell us something significant about the colonial past and the contemporary observer; that hybridity is not unilinear (that is, the material culture used by colonizers displays hybrid attributes just as much as that of the colonized); and that hybridity makes its most significant anthropological contribution in its attention to power dynamics.

\section{Wagon Trains and First Fleets: Hybrid Indigenous-Colonial Whips}

In the waning decades of the nineteenth-century, collectors of Native American memorabilia lamented what they perceived to be the inexorable decline of American Indian arts and crafts. Access to the resources necessary for the production of "traditional" material culture was being stripped from the Arapaho, Blackfeet, Cheyenne, Crow, Lakota, and other iconic tribes of the American Plains. By the mid-1890s carved bison horns had been replaced by those of mere dairy cattle. War bonnets were being festooned with turkey feathers rather than eagle plumes. The scalps for sale at trading posts throughout the American West were no longer torn from human heads, but replicas fabricated out of horsehair glued to pieces of sheepskin. "Today, the gentle tourist is being swindled with this bogus stuff," bemoaned Julian Ralph, a reporter for Scribner's Magazine, “made by diluted Indians from white men’s patterns" (1896:639). But even as collectors decried these curios as inauthentic, one subcategory of equally nontraditional Indian objects began to draw their attention - items that combined Native American material culture with "the waste and wreckage of the white man." Collectors across the country admired the ingenuity of "converted goods [that] have relapsed from civilization into barbarism": a section of stovepipe repurposed to make a tom-tom drum; tin ear rings cut from the bottom of a 
tomato can; metal tinklers fashioned out of discarded chewing tobacco containers (Ralph 1896:645).

One class of artifact that caught nineteenth-century collectors' eyes was a new style of Northern Plains quirt (a short-handled riding whip). Rather than a "traditional" grip made of elk or deer antler, these new quirts sported handles fashioned out of wood [FIG. 2]. The wooden handles were often cylindrical, carved on a lathe (rather than whittled with a blade), and studded with brass tacks. Some had empty sockets bored into the side, evincing a previous life as something other than horse tack. The florescence of these wooden-handled quirts in the nineteenth century is no accident. They began to appear shortly after the first wagon trains traversed the American West along the famous trails to Oregon, Bozeman, and Santa Fe. Loaded with the cargo of white settlers, these wagon trains were frequent targets of Native American raids. In these attacks settlers were often separated from their possessions: clothing; tools; pots and pans; and in many cases, their furniture. While the Native warriors who collected these spoils had no need for bedroom sets, breakfronts, and dining tables, they did find a use for many of the settlers' furnishings. They recycled the brass tacks from seatbacks and cushions to decorate wooden objects. The legs of a chair could also be broken off and reused - providing ideal handles for their quirts. Reporting for Scribner's, Ralph described one example of these furniture-leg quirts as "more beautiful, and to me more valuable, than the entire original bedroom set of which it once formed a part" (1896:645).

The quirts that lashed the haunches of nineteenth century horses across the Great Plains are not the only hybrid whips to emerge out of early Indigenous contacts with Europeans. A century earlier, on the other side of the world, Aboriginal Australian material culture melded with British naval justice to fashion an analogous whip when the famed 1788 First Fleet expedition founded a British penal colony in Australia [FIG. 3]. 
The HMS Supply led the way among the vessels of the First Fleet, staffed with a ship's master named Lt. David Blackburn. Ships' masters in His Majesty’s Royal Navy shouldered many responsibilities, but the most critical entailed the disbursement of alcohol to the crew and the resulting administration of onboard discipline. In cases of serious transgressions such as insolence, stealing, and mutiny, Naval law prescribed flogging as the standard punishment. Each ship's master carried his own lash for these occasions. Lt. Blackburn's whip approximated a cato'-nine-tails, comprising four knotted ropes bound to a wooden handle.

Like the furniture-leg quirts, the handle of Master Blackburn's whip was no ordinary stick. Cylindrical in shape (but not turned on lathe), the hardwood shaft shined from countless hours gripped in a man's palm. Shallow striations along its length reveal that the handle's maker carved it by hand, probably with a sharp shell blade. Its form, proportions, and material match that of an Aboriginal wudi - "part missile, part bludgeon"- a weapon that the men of eighteenthcentury southeast Australia carried for self-defense. Master Blackburn apparently acquired the wooden club when the First Fleet made landfall at Botany Bay on Australia's east coast. Today, Blackburn's whip represents the only surviving wooden object hailing from the First Fleet's initial encounter with Aboriginal people (Jones 2007:12-18).

\section{Interpretations}

Centuries after collectors plucked these whips from their original contexts, they remain treasured and revered in museum collections today. Their survival through the centuries attests to the fascination that such culturally "mixed" objects held for collectors of the eighteenth and nineteenth centuries, a time ironically obsessed with preserving pristine Indigenous authenticity. Part of this fascination, no doubt, was the apparent contradiction that double objects embodied for their collectors. Nineteenth-century ethnologists and travellers expected Native Americans 
to cling stubbornly to "traditional" ways of life and material culture. Evidence of adaptation and ingenuity, such as furniture-leg quirts, challenged dominant views of Indigenous peoples as culturally stagnant and incapable of adopting new ways of life (Rowlands 2011:183-84). On the other hand, evidence of colonists' adoption of Aboriginal material culture - embodied in Master Blackburn's whip — may have challenged Europeans' assumptions about the utility of Indigenous technology (or lack thereof) in their modern world.

But did the makers of these whips view them as hybrid objects, or are we simply projecting our own expectations onto the past when we choose to call them hybrids? Were these quirts remarkable to the Apache, Blackfoot, Cheyenne, and Lakota warriors who carried them, or were they just plain old whips? Did their nineteenth-century owners view them as a hybrid fusion of Euro-American culture with that of their Native forebears? In every society, some objects of "mixed" heritage are deemed unremarkable, with their multicultural origins overlooked. Naturalized over time, these double objects fade from the realm of discourse into the fog of doxa. Was this the case with furniture-leg quirts?

On the one hand, we could argue that the furniture-leg quirts are simply relics embodying opportunistic appropriations of available resources. Maybe they fit into long-held practices of "recycling" that characterized Plains cultures stretching back into pre-contact times. However, this interpretation does not capture the full range of meanings evoked by these quirts to their owners. It overlooks the fact that the capture and display of enemy trophies was a common practice among Plains horse cultures (Calloway 1996:61-62). Nineteenth-century Plains warriors displayed their victories and conquests publicly, accomplished in part through the clothes they wore and the paraphernalia they carried. Young men commonly decorated themselves - and their horses - with plunder captured from their enemies, both Native and nonNative. These trophies conspicuously documented their victories. Furniture-leg quirts formed 
part of this larger category of war trophies. That is, they were seen as special and meaningful to the men who carried them precisely because of their hybrid origins. The quirts were, in other words, the products of conscious hybridity meant to evoke their menacing and disquieting alterity. They were conspicuous tools of Native resistance to Euro-American settlement.

Master Blackburn's whip is a different case, however. His aboriginal cat-o'-nine-tails symbolized very different things from the furniture-leg quirts of the American Plains.

Blackburn's whip was menacing because of its function, not because of its origins. But this isn't to say that the lash's mixed background was insignificant in its day. Lt. Blackburn and his British compatriots likely found his whip - like other objects of British Imperial expansion — to be remarkable, and thus collectable, precisely because of its cosmopolitan pedigree. Ironically, that pedigree seems to have been forgotten for most of the twentieth century, and when the whip came up for auction at Sotheby's of London in 1999 just one lone bidder recognized its Australian origins (Jones 2007:13). Since that time the whip has gained fame as the only surviving wooden artifact from the First Fleet's encounter with Aboriginal people, transforming it into a cherished piece of Australia's cultural heritage. Indeed, the Australian Government recognized Master Blackburn's whip as an object of "exceptional cultural importance" in 2013, adding it to a list of items banned from ever leaving the country in order to ensure "that significant cultural heritage objects are preserved for the benefit of all Australians." 1 Thus in the eyes of both late eighteenth-century British sailors and twenty-first century Australians, Blackburn's whip is recognized as a hybrid object.

\section{Hybridity in Seventeenth-Century Pueblo Ceramics}

In 1539, the Indigenous peoples of the American Southwest encountered foreigners from across the Atlantic for the first time. Over the next six decades Franciscan friars, Spanish 
conquistadores, and enslaved Africans made sporadic appearances in the plazas of stone and adobe villages scattered across the region they christened "the new Mexico." The Spaniards called the maize farmers who lived in these villages indios de pueblos to distinguish them from the nomadic hunter-gatherers who roamed the surrounding regions. These Pueblo Indians shared broad similarities in the architecture of their villages, farming and hunting practices, religion, political organization, and material culture. They also produced and used fine ceramic vessels, which the Spaniards recognized as comparable to the pottery upon which the colonizers were accustomed to dining. In the Rio Grande valley, Pueblo potters had even mastered the art of lead-glaze decoration, similar to the majolica ceramics favored by the Spaniards.

With the establishment of Franciscan missions and permanent colonial settlements in 1598, Spanish and Pueblo cultures became thoroughly entwined in New Mexico. The influence of the Pueblos transformed the local Spanish colonial economy, architecture, cuisine, and dressand vice-versa. Moreover, Spanish colonialism altered Pueblo agricultural practices, political organization, settlement patterns, and religion. Indeed, the tendrils of colonial power reached even into the most "traditional" of Pueblo crafts, the production of their pottery. After 1598, Pueblo women began producing new forms of pottery that mimicked those used by Spanish colonists, including teacups, porringers, candlestick holders, chamber pots, shaving bowls, baptismal fonts, and crosses, among other items (Dyer 2010:38; Lambert 1981:224-28; Liebmann 2012:132).

Soup Plates

The most common of these new, Spanish-inspired Pueblo ceramics was the form known as the soup plate [FIG. 4]. Soup plates are small, shallow bowls with flaring everted rims. Used as personal serving vessels for a single individual, Pueblo women produced soup plates using local 
clays, tempers, slips, and paint. Soup plates are frequently found at seventeenth-century Pueblo mission villages throughout the Southwest, and are considered to be one of the diagnostic ceramic types of the early Spanish colonial period (ca. AD 1598-1700) in Arizona and New Mexico. Their appearance in early colonial ceramic assemblages presumably reflects a change in the cuisine consumed throughout the region under Spanish rule as well. The discussion that follows draws primarily on the work of Jennifer Boyd Dyer (2010), whose superlative analysis comprises the most comprehensive investigation of Southwestern soup plates conducted to date.

The presence of soup plates in the archaeological record of the Pueblos presents a number of questions. Why and how were the soup plates made, and by whom? Who actually dined on them? Where are they found? Were soup plates seen as an intentional combination of Pueblo technology and Spanish form? Or did they evolve organically, as a natural outgrowth of colonial interactions? Most importantly for the topic at hand, do we learn anything new when we call these soup plates hybrids?

Soup plates have been documented in a variety of archaeological contexts throughout the seventeenth-century Pueblo world (Dyer 2010:79). They are found at mission pueblos (i.e. Pueblo villages at which Franciscan friars established mission facilities); at Spanish colonial sites (including the colonial capitol in Santa Fe); and at non-missionized Pueblo villages and rural field houses (small dwellings of typically one to two rooms adjacent to Pueblo agricultural fields [Preucel 1990:42; Kulisheck 2005]). In other words, soup plates are found at seventeenthcentury sites occupied principally by Spaniards, at sites occupied principally by Puebloans, and at sites where Spaniards and Puebloans lived side-by-side.

Pueblo women manufactured the majority of soup plates found in northern New Mexico. They were not imported from Spain or Mexico. The fabric of the soup plates generally mimics that of locally made Puebloan vessels. They use the same tempering materials, with clays derived 
from the same local sources. Furthermore, soup plates were produced using long held regionallyspecific techniques of vessel construction, decoration, and firing that could only be learned through a process of apprenticeship at the knee of a knowledgeable Pueblo potter (Dyer 2010:239-41).

It seems likely that Pueblo potters initially produced soup plates at the behest of Spanish colonists. These new bowls were not incorporated into longstanding inter-Pueblo trade networks in the same way as traditional Pueblo vessels, suggesting that they were initially produced for something other than normal Pueblo consumption. Yet they do not appear to have been made under direct Spanish supervision or exacting strictures, either. Soup plates exhibit a high degree of variability in surface decoration, vessel size, form, and composition, suggesting that their production was not standardized (Dyer 2010:219, 238).

While some of these bowls were used to serve Spaniards, soup plates eventually pried their way into the fabric of Pueblo life as well. Pueblo people dined on them at their field houses (Boyd and Constan 2002). This was ground trampled only by the yucca sandals that adorned Pueblo feet, not the leather of Spaniards' boots. This migration of soup plates from the tables of Spaniards into traditional Pueblo maize fields attests to the pervasive nature of colonial power, which works its ways into the smallest crannies of everyday activity. Spanish colonialism invariably reached into the private corners of Pueblo domestic life, changing Native foodways through the introduction of cattle, sheep, and scores of new crops (Ford 1987; Spielmann et al. 2009). These transformations in cuisine had a domino effect on Pueblo ceramic production, resulting in the manufacture of new forms such as the soup plate to better accommodate changing diets.

Although Pueblo women manufactured these new forms in a fashion similar to that of their traditional pottery, Dyer (2010:238-39) notes that the producers of soup plates did not 
simply apply conventional ceramic technologies straightforwardly. Soup plates differ from traditional (i.e. pre-Hispanic) Pueblo vessels not only in their form, but also in the way the clay was prepared (resulting in dissimilarities in the size and frequency of voids within the matrix, for example), the temperature at which they were fired, and their surface decoration. When they made soup plates, Pueblo potters were not utilizing the same time-honored, pre-Hispanic techniques they used to produce traditional bowls and simply manufacturing new forms. Soup plates combined traditional Pueblo crafts with Spanish influences in modified and innovative ways.

Did the Spaniards and Pueblo people who ate out of these bowls consider them to be a hybrid fusion of colonizer and colonized? Or was this an example of entanglement - the organic, unconscious melding of Pueblo and Spanish lifeways? When I began to ponder these questions, I first assumed that the adoption of soup plates into Pueblo pottery repertoires was largely unintentional, a by-product of the new foods and recipes introduced by the Spaniards. In other words, these bowls were a functional response to the ways in which new foods were being prepared and eaten. However, Dyer convincingly argues that Pueblo intention and choice played a primary role in soup plate production $(2010: 219,239-40)$. Soup plates were not produced indiscriminately, haphazardly, or arbitrarily. Their decoration encoded intentional meanings that signaled Pueblo identities, suggesting that their makers were indeed aware of the fusion of Native ethnicities with Spanish forms embodied within every soup plate.

Like "traditional" pre-Hispanic and early seventeenth-century Pueblo pottery, the decoration of soup plates varied according to the region in which they were produced. Soup plates manufactured in the Pueblos north of Santa Fe are different from those produced to the south, and Pueblos east of the Rio Grande made soup plates different from those on the mesas west of the river. These regional differences suggest that potters at each pueblo produced soup 
plates according to their own aesthetic tastes, not those of the Spaniards. These tastes were tied to group identities at individual Pueblo villages. Each soup plate signaled meaningful information regarding the place it was made and the household of which it was a part. In other words, the potters who produced soup plates intentionally combined a new Spanish form (everted-rim bowls) with traditional, regionally specific Pueblo decoration. That they were conscious of this fusion seems more than likely, as they deliberately applied their own ethnicallyspecific twists to soup plate production at every turn.

Labeling soup plates as hybrid vessels calls attention to the dynamic ebb-and-flow of colonial power in seventeenth-century New Mexico. The presence of these new forms at Pueblo sites reveals the range and scope of Spanish colonial influence, and the churning domination of colonial power. But their intentional decoration speaks to the ways in which Pueblo peoples insisted on putting their own stamp on that influence as well. This was a strategic choice that pushed back against the colonial machine, changing the contexts in which soup plates could be used and opening up innovative new spaces in which "Puebloness" could be performed. The decision to decorate soup plates in the styles of traditional Pueblo pottery likely made their introduction to Pueblo society more palatable to those reluctant to adopt new ways, smoothing the path for the introduction of the new foods they contained as well. By identifying soup plates as hybrid, then, we underscore both the unconscious creep of colonial power into Pueblo life and the strategic negotiation of the accompanying changes by colonized subjects.

\section{The Giusewa Chalice}

From the other end of the colonizer-colonized spectrum comes a final case of SpanishPueblo fusion: a stemmed ceramic chalice from the ancestral Jemez pueblo of Giusewa [FIG. 5]. Chalices are integral to the Catholic mass and the celebration of the sacrament of Eucharist, as 
they hold the wine that is transformed into the Blood of Christ. The Giusewa chalice is made in the style of traditional Pueblo pottery known as Jemez Black-on-white, a ceramic type that was manufactured from A.D. 1375 to 1680 in the Jemez Province of northern New Mexico (Elliott 1994; Liebmann 2008).

This chalice was excavated in 1937 during archaeological investigations of the convento complex (the priest's quarters and adjoining mission support structures) of an early seventeenthcentury Franciscan mission at Giusewa (Toulouse 1937; Reiter 1938:82). It can be securely dated to between 1598-1659, the years in which the mission was actively in use (although Pueblo occupation of Giusewa stretches back as far as the fourteenth century). But the intra-site archaeological context of the chalice suggests that it was likely manufactured, used, and discarded between 1598 and 1601 (Liebmann 2013:35).

The fusion of a Christian form with a traditional Jemez ceramic type suggests that the artifact was commissioned by a Friar and manufactured by one of the women at Giusewa. The proportions of the Giusewa chalice correspond to the standard size and shape of typical chalices of the period, suggesting that either its creator was personally familiar with these vessels, ormore likely - that someone intimately acquainted with chalices oversaw the manufacturing process. Possibly the potter copied the form of another chalice that the Friar brought with him to Giusewa. The mixing of the two traditions is further evident in the decoration of the chalice, which combines the Jemez convention of concentric lines encircling the upper register of the inside of the bowl with the Christian crosses that adorn the bottom of the bowl interior and the underside of the base.

Viewing the Giusewa chalice through the lens of hybridity exposes the many different perspectives from which this curious artifact may be viewed. It is hard to argue that the chalice is anything other than a product of intentional hybridity. Because priests typically carried with 
them the tools of their trade when assigned to a new post, it seems likely that the Friar would have brought his own personal chalice with him when stationed at Giusewa in 1598. The commissioning of a chalice in Jemez Black-on-white seems to have been an intentional attempt to materialize Christian paraphernalia in a form more familiar to the Jemez people. This effort to localize the exotic and indigenize the foreign comprised part of a larger strategy of Franciscans in early seventeenth-century New Mexico to introduce Catholicism to the Pueblos "gingerly," in the words of historian David Weber (1992:10). By dressing the Eucharistic ritual in clothing more familiar to the Jemez, the Friar hoped to entice the people of Giusewa to convert to Christianity.

The production of the Giusewa chalice was a strategic choice of the Friar, a forcing together of two formerly separate cultural traditions. This was not a natural, organic fusion-it was not, to paraphrase Bhabha, a happy, consensual making-do. Rather, the chalice embodies a calculated attempt to weld Catholicism onto Pueblo society. While we cannot know exactly how the Jemez received this attempted melding, the chalice literally embodied the re-shaping of Jemez culture to fit a Christian mold - a metaphor for life under the mission bell for the inhabitants of Giusewa. Bolstering this interpretation of Jemez perspectives on the hybrid chalice is that fact that eventually - and ironically, from the perspective of the Friars - this forcing together of colonizer and colonized led to the demise of the Jemez Black-on-white tradition entirely. Following the Pueblo Revolt of 1680, the Jemez people deliberately ceased production of their age-old ceramic tradition, adopting totally new and different types of pottery. According to contemporary Jemez oral tradition, this termination of Jemez Black-on-white was a direct response to the Spanish colonial "contamination" that had tainted this pottery tradition throughout the seventeenth-century (Liebmann 2012:132).

I choose the example of the Giusewa chalice because it explicitly pushes back against the notion that hybridity is a one-way street. Here we have an example of an artifact produced for 
and used primarily by European colonizers that is also indubitably a "double object."

Excavators have unearthed other hybrid Spanish-Pueblo artifacts made in the Jemez Black-onwhite style at Giusewa as well, including a sconce, candelabra, soup plates, cups, and a cross (Lambert 1981). All of these can be productively interpreted through the lens of hybridity, which has the advantage of highlighting the power dynamics at play in early seventeenth-century New Mexico. The cultural appropriation inherent in the production of hybrid Catholic ecclesiastical forms in Jemez Black-on-white throws into high relief the attempt to colonize, Hispanicize, and Christianize the inhabitants of Giusewa.

\section{Concluding Thoughts on Hybridity}

Because all cultural phenomena are socially acquired and therefore collective, they are inherently heterogeneous. Cultural worlds are filled with mixture. Amalgamation is the norm, not the exception to the rule. The identification of hybridity, however, is the identification of an exception to the rules (or at least what is perceived to be an exception)-something that became different through mixture. Not all mixtures are the same though, and we need a multitude of ways to describe the variety of mixtures that enliven cultural worlds. Hybridity is one way to describe those mixes that challenge our presumptive norms. It also emphasizes the transfer of power that occurs within the process of mixing, and for that reason, hybridity can be particularly useful for the investigation of colonial encounters. It makes us question what is Indigenous and what is foreign, as well as where the boundaries of those categories lie.

Hybridity is not an object or even a quality, but a process. And because hybridity does not inhere in objects themselves, it is always and everywhere in the eye of the beholder. This means that the identification of hybridity in archaeological contexts tells us as much about ourselves as it does about the past. But this should not diminish the usefulness of the concept. 
We need such tools to identify our own biases and preconceptions. At the end of the day, however, archaeologists tend to be more interested in learning about the past than the present. So it seems legitimate to ask: in identifying some objects as products of hybridity while ignoring the complicated, multi-cultural backgrounds of others, are we fooling ourselves? Are we projecting our own assumptions onto the archaeological record, creating a past in our own image and likeness? Does the use of this term get us closer to emic understandings of double objects or farther away from them? Does hybridity muddy the archaeological waters rather than allowing us to see the bottom?

Returning to the case of the Mickey Mouse kachina dolls, for Hopis of the early twentieth century there was no apparent contradiction between Mickey Mouse and "traditional" cultural practices. They were integrated seamlessly, and whether the carvers of Mickey Mouse tithu would have viewed them as hybrid is unknown. Yet today, the perceived combination of a "traditional" form with "modern" subject matter is what draws the attention of researchers. Interestingly, the Mickey Mouse kachina doll in the Smithsonian Institution collections is housed in the National Museum of American Art, not the National Museum of the American Indian (Green 1991; Lavender 2012). Most non-Native people-anthropologists, museum curators, and non-academics alike - conceive of Indigeneity in opposition to capitalist modernity, and see the Mickey Mouse kachina as non-traditional and an example of hybridity.

Using hybridity as a catchall term to describe every instance of cultural mixture is a mistake, to be sure. But I am not yet ready to condemn this concept to the archaeological graveyard, for two reasons. First, by foregrounding the power dynamics inherent in situations of cultural melding, hybridity provides an alternative to more benign concepts of cultural mixing. No other term commonly used to designate cultural mixture (acculturation, syncretism, creolization, and entanglement, among others) focuses our attention — implicitly or explicitly —on 
the exchanges of power that simultaneously center and marginalize. These exchanges were integral to the processes of colonialism, and to overlook them risks ignoring a vital piece of the colonial past. The identification of hybridity is not simply a recognition of mixing or of cultural difference, but a recognition of the traces of hegemonic forces through which colonial cultures are formed (Dean and Leibsohn 2003:26).

Furthermore, there were instances in the past where cultural combinations were calculated, potent, and meaningful to the agents who produced them - and the audiences who viewed them. That is, objects can be recognized as hybrids in their own time. The challenge for archaeologists is to discern these instances of intentional hybridity the past. There is no easy-tofollow recipe for this. Hybridity is a concept seething with seeming contradictions. It is both a frequent tactic of subalterns and an obvious strategy of colonizers. It can be a tool of resistance and an instrument of domination. It is ordinary and everywhere and yet powerfully transgressive. It seems to demand purity, yet it celebrates heterogeneity. In the end, however, the identification of hybridity alerts us to be wary of our own assumptions. It also helps to unmask the traces of power and inequity etched into the past wherever and whenever cultural differences met.

\section{Acknowledgements}

Thanks to Steve Silliman and Diana Loren for their advice, encouragement, and critical thoughts on all things hybrid. Thanks too to Peter van Dommelen and Alicia Jiménez for inviting me to present these ideas at the Hybridity in Practice workshop at the Joukowsky Institute for Archaeology, Brown University, and to Bob Preucel for his thoughtful discussion there. I also thank Bridget Alex, Jessica Cerezo-Román, Rowan Flad, Richard Meadow, Max Price, Adam 
Stack, Jason Ur, Sadie Weber, and two anonymous reviewers for their insightful comments on previous versions of this paper.

${ }^{1}$ http://arts.gov.au/movable/export/register 


\section{Bibliography}

Ackermann A. (2012) Cultural Hybridity: Between Metaphor and Empricism. In: Stockhammer P (ed) Conceptualizing Cultural Hybridization: A Transdisciplinary Approach. Berlin: Springer, 525.

Bakhtin M. (1981) The Dialogic Imagination Austin: University of Texas Press.

Barth F. (1969) Introduction. In: Barth F (ed) Ethnic Groups and Boundaries. Boston: Little, Brown, and Company, 9-37.

Bhabha HK. (1994) The Location of Culture, London: Routledge.

Bourdieu P. (1977) Outline of a Theory of Practice, Cambridge: Cambridge University Press.

Boyd JE and Constan CI. (2002) Ceramics on Lower Virgin Mesa, Jemez Mountains, New Mexico.

Report on File, Santa Fe National Forest, Santa Fe.

Calloway CG. (1996) Our Hearts Fell to the Ground: Plains Indian Views of How the West Was Lost, Boston: Bedford/St. Martin's.

Capone S. (2013) Do We Need Über-Terms for "Cultural Mixture"? Current Anthropology 54: 474475.

Card JJ. (2013) The Archaeology of Hybrid Material Culture. Carbondale: Southern Illinois University Press.

Dawdy SL. (2008) Building the Devil's Empire: French Colonial New Orleans, Chicago: University of Chicago Press.

Deagan K. (2013) Hybridity, Identity, and Archaeological Practice. In: Card JJ (ed) The Archaeology of Hybrid Material Culture. Carbondale: Southern Illinois University Press, 260276.

Dean C and Leibsohn D. (2003) Hybridity and Its Discontents: Considering Visual Culture in Colonial Spanish America. Colonial Latin American Review 12: 3-35.

Dietler M. (2010) Archaeologies of Colonialism: Consumption, Entanglement, and Violence in Ancient Mediterranean France, Berkeley: University of California Press.

Dyer JB. (2010) Colono Wares in the Western Spanish Borderlands: A Ceramic Technological Study. Unpublished PhD Dissertation, University of New Mexico Department of Anthropology.

Elliott ML. (1994) Jemez Area Ceramics. Report on File, Santa Fe National Forest, Santa Fe.

Ford RI. (1987) The New Pueblo Economy. In: When Cultures Meet: Remembering San Gabriel del Yungue Oweenge. Santa Fe: Sunstone Press, 73-91.

Gilroy P. (2000) Against Race: Imagining Political Culture beyond the Color Line: Harvard University Press.

Green R. (1991) The Mickey Mouse Kachina. American Art: 208-209.

Hall S. (1990) Cultural Identity and Diaspora. In: Rutherford J (ed) Identity, Community, Culture, Difference. London: Lawrence and Wishart.

Hodder I. (2012) Entangled: An Archaeology of the Relationships between Humans and Things. Malden: Wiley-Blackwell.

Howey MCL. (2011) Colonial Encounters, European Kettles, and the Magic of Mimesis in the Late Sixteenth and Early Seventeenth Century Indigenous Northeast and Great Lakes. International Fournal of Historical Archaeology 15: 329-357.

Hutnyk J. (2005) Hybridity. Ethnic and Racial Studies 28: 79-102.

Johnson PC. (2013) Comments on Palmié's "Mixed Blessings and Sorrowful Mysteries." Current Anthropology 54: 477-478.

Jones P. (2007) Ochre and Rust: Artefacts and Encounters on the Australian Frontier, Kent Town:

Wakefield Press. 
Jopling CF. (1989) The Coppers of the Northwest Coast Indians: Their Origin, Development, and Possible Antecedents. Philadelphia: American Philosophical Society.

Kapchan DA and Strong PT. (1999) Theorizing the Hybrid. Fournal Of American Folklore 112: 239253.

Kennard E, Yava A and Kabotie F. (1944) Field Mouse Goes to War/Tusan Homichi Tuwrota: A Bilingual Hopi Tale, Washington D.C.: Education Division, U.S. Indian Service.

Kraidy M. (2005) Hybridity, or the Cultural Logic of Globalization, Philadelphia: Temple University Press.

Kulisheck J. (2005) The Archaeology of Pueblo Population Change on the Femez Plateau, A.D. 1200-1700: The Effects of Spanish Contact and Conquest. University Microfilms, Ann Arbor: PhD Dissertation, Department of Anthropology, Southern Methodist University.

Lambert MF. (1981) Spanish Influences on the Pottery of San Jose de los Jemez and Giusewa, Jemez State Monument (LA 679), Jemez Springs, New Mexico. In: Schroeder AH (ed) Collected Papers in Honor of Erik Kellerman Reed. Albuquerque: Albuquerque Archaeological Society Press, 215-236.

Lavender C. (2012) Picturing the West 4-Thoughts at the End of the Trail. http:/ / picturinghistory.gc.cuny.edu/?p=867

Levi-Strauss C. (1963) Totemism, Boston: Beacon Press.

Liebmann M. (2008) The Innovative Materiality of Revitalization Movements: Lessons from the Pueblo Revolt of 1680. American Anthropologist 110: 360-372.

Liebmann M. (2012) Revolt: An Archaeological History of Pueblo Resistance and Revitalization in 17 th Century New Mexico, Tucson: University of Arizona Press.

Liebmann M. (2013) Parsing Hybridity: Archaeologies of Amalgamation in Seventeenth-Century New Mexico. In: Card JJ (ed) The Archaeology of Hybrid Material Culture. Carbondale: Southern Illinois University Press, 25-49.

Loren DD. (2013) Considering Mimicry and Hybridity in Early Colonial New England: Health, Sin, and the Body 'Behung with Beades'. Archaeological Review From Cambridge 28: 151-168.

Mullins PR. (2011) The Archaeology of Consumption. Annual Review of Anthropology, Vol 4040 : 133-144.

Palmie S. (2013a) Mixed Blessings and Sorrowful Mysteries: Second Thoughts about "Hybridity". Current Anthropology 54: 463-482.

Palmie S. (2013b) Signal and Noise: Digging up the Dead in Archaeology and Afro-Cuban Palo Monte. Archaeological Review From Cambridge 28: 115-132.

Preucel RW. (1990) Seasonal Circulation and Dual Residence in the Pueblo Southwest : A Prehistoric Example from the Pajarito Plateau, New Mexico, New York: Garland Pub.

Ralph J. (1896) My Indian Plunder. Scribner's Magazine 20: 637-645.

Reiter P. (1938) The Jemez Pueblo of Unshagi, New Mexico, Albuquerque: University of New Mexico Press.

Rowlands S. (2011) Entangled Frontiers: Collection, Display and the Queensland Museum, 1878-1914. Fournal of Australian Colonial History 13: 183-206.

Rushdie S. (1991) Imaginary Homelands: Essays and Criticism, 1981-1991, London: Granta Books.

Seshadri-Crooks K. (2000) Surviving Theory: A Conversation with Homi K. Bhabha. In: AfzalKhan F and Seshadri-Crooks K (eds) The Pre-Occupation of Postcolonial Studies. Durham: Duke University Press.

Silliman S. (2013) What, Where, and When is Hybridity? In: Card JJ (ed) The Archaeology of Hybrid Material Culture. Carbondale: Southern Illinois University Press, 486-500. 
Silliman S and Witt TA. (2010) The Complexities of Consumption: Eastern Pequot Cultural Economics in Eighteenth-Century New England. Historical Archaeology 44: 46-68.

Spielmann KA, Clark T, Hawkey D, et al. (2009) "...being weary, they had rebelled": Pueblo Subsistence and Labor under Spanish Colonialism. Journal Of Anthropological Archaeology 28: 102-125.

Spivak GC. (1990) Poststructuralism, Marginality, Post-coloniality and Value. In: Collier P and Geyer-Ryan H (eds) Literary Theory Today. Ithaca: Cornell University Press, 219-244.

Stockhammer P. (2012) Conceptualizing Cultural Hybridization: A Transdisciplinary Approach, Heidelberg; New York: Springer Verlag.

Stockhammer P. (2013) From Hybridity to Entanglement, from Essentialism to Practice. Archaeological Review From Cambridge 28:11-28.

Thomas N. (1994) Colonialism's Culture: Anthropology, Travel, and Government, Cambridge: Polity Press. Thomas N. (1996) Cold fusion. American Anthropologist 98: 9-16.

Toulouse J, Jr. (1937) Excavations at San Diego Mission. New Mexico Anthropologist 2: 16-18.

Turgeon L. (1997) The Tale of the Kettle: Odyssey of an Intercultural Object. Ethnohistory 44: 129.

van Dommelen P. (2005) Colonial Interactions and Hybrid Practices: Phoenician and Carthaginian Settlement in the Ancient Mediterranean. In: Stein GJ (ed) The Archaeology of Colonial Encounters: Comparative Perspectives. Santa Fe: School of American Research Press, 109-141.

van Dommelen P. (2011) Postcolonial Archaeologies between Discourse and Practice. World Archaeology 43: 1-6.

van Dommelen P and Rowlands M. (2012) Material Concerns and Colonial Encounters. In: Maran J and Stockhammer PW (eds) Materiality and Social Practice: Transformative Capacities of Intercultural Encounters. Oxford: Oxbow Press, 20-31.

VanValkenburgh P. (2013) Hybridity, Creolization, Mestizaje: A Comment. Archaeological Review From Cambridge 28: 301-322.

Weber DJ. (1992) The Spanish Frontier in North America, New Haven: Yale University Press.

Werbner P. (1997) Introduction: The Dialectics of Cultural Hybridity. In: Werbner P and Modood T (eds) Debating Cultural Hybridity. London: Zed Books, 1-26.

Wolf ER. (1982) Europe and the People Without History, Berkeley: University of California Press.

Wu X. (2013) Cultural Hybridity and Social Status: Elite Tombs on China's Northern Frontier during the Third Century BC. Antiquity 87: 121-136.

Young RJC. (1995) Colonial Desire: Hybridity in Theory, Culture, and Race, London: Routledge. 


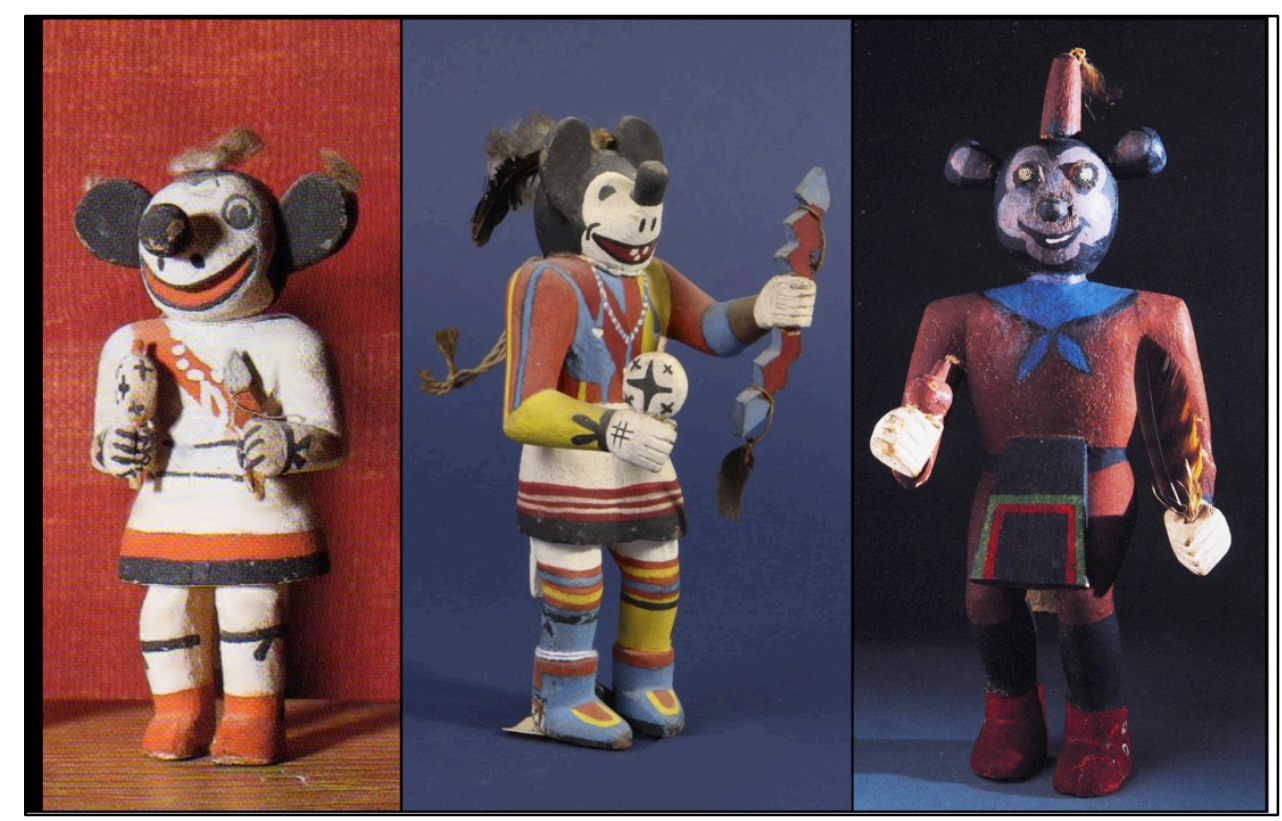

Figure 1: Mickey Mouse Kachina Dolls, circa 1930-1955. left: anonymous private collection; center: Otis Dozier Collection, Dallas; right: National Museum of American Art, Smithsonian Institution. (Image collage by Matthew Liebmann.) 


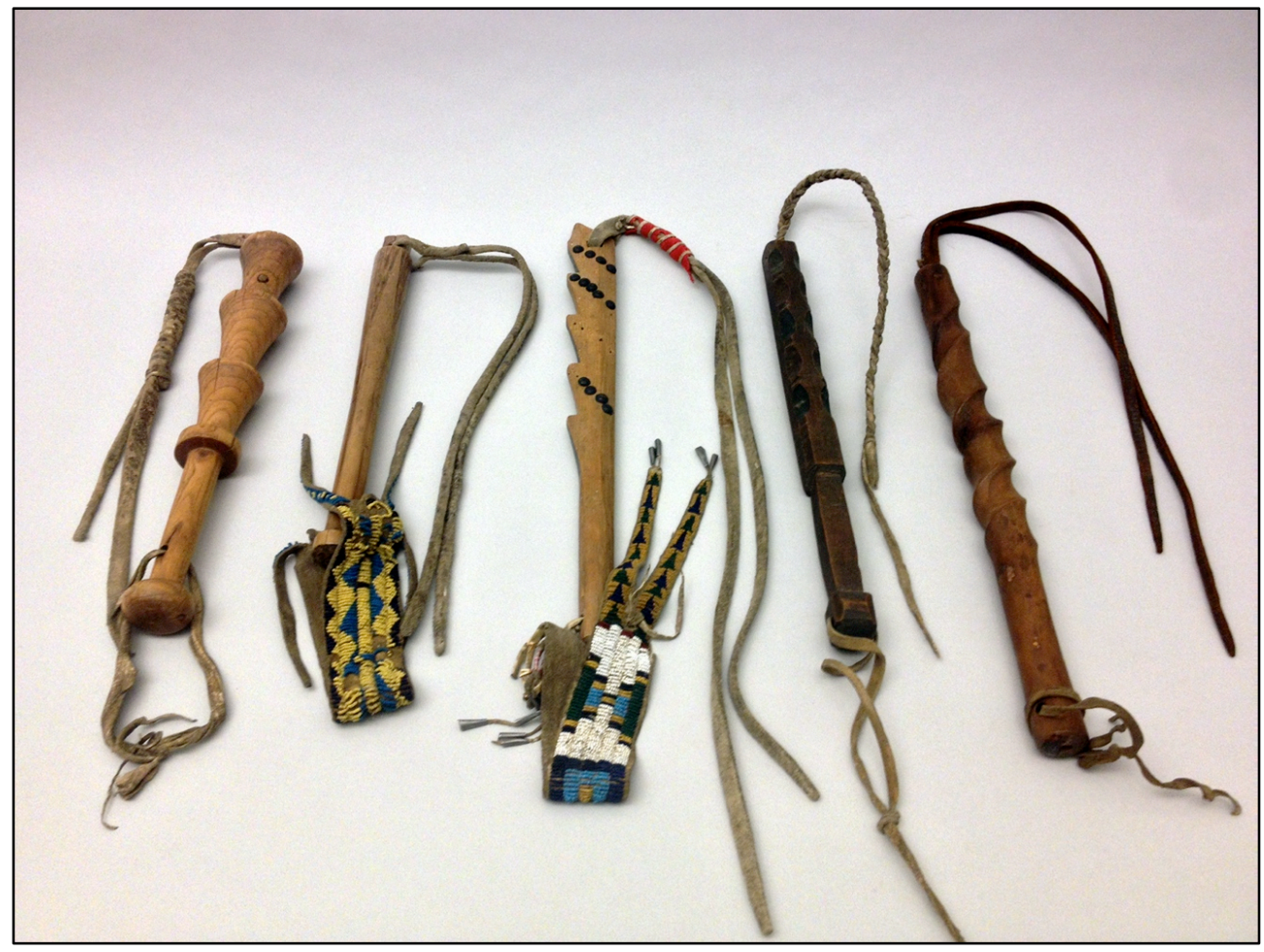

Figure 2: Wooden-handled quirts from the North American Plains in the collections of the Peabody Museum of Archaeology and Ethnology, Harvard University (Photo by Matthew Liebmann) 


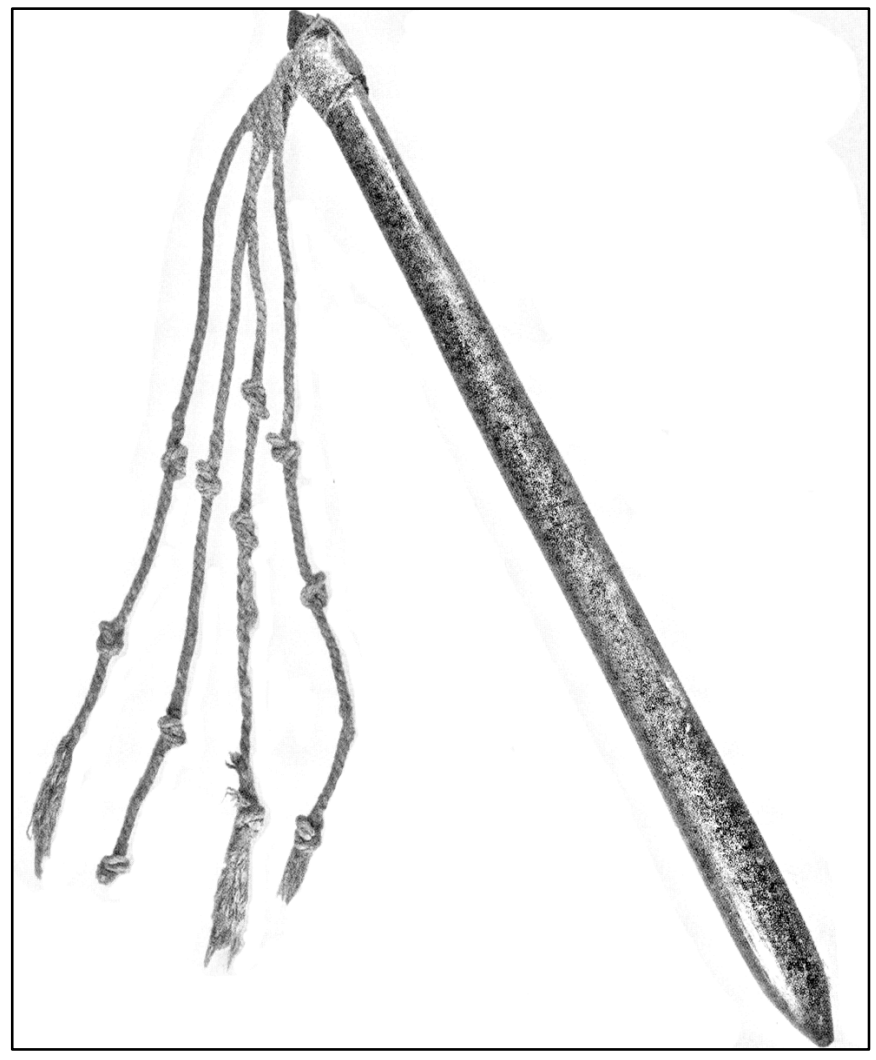

Figure 3: Master Blackburn's Whip (after Jones 2007) 


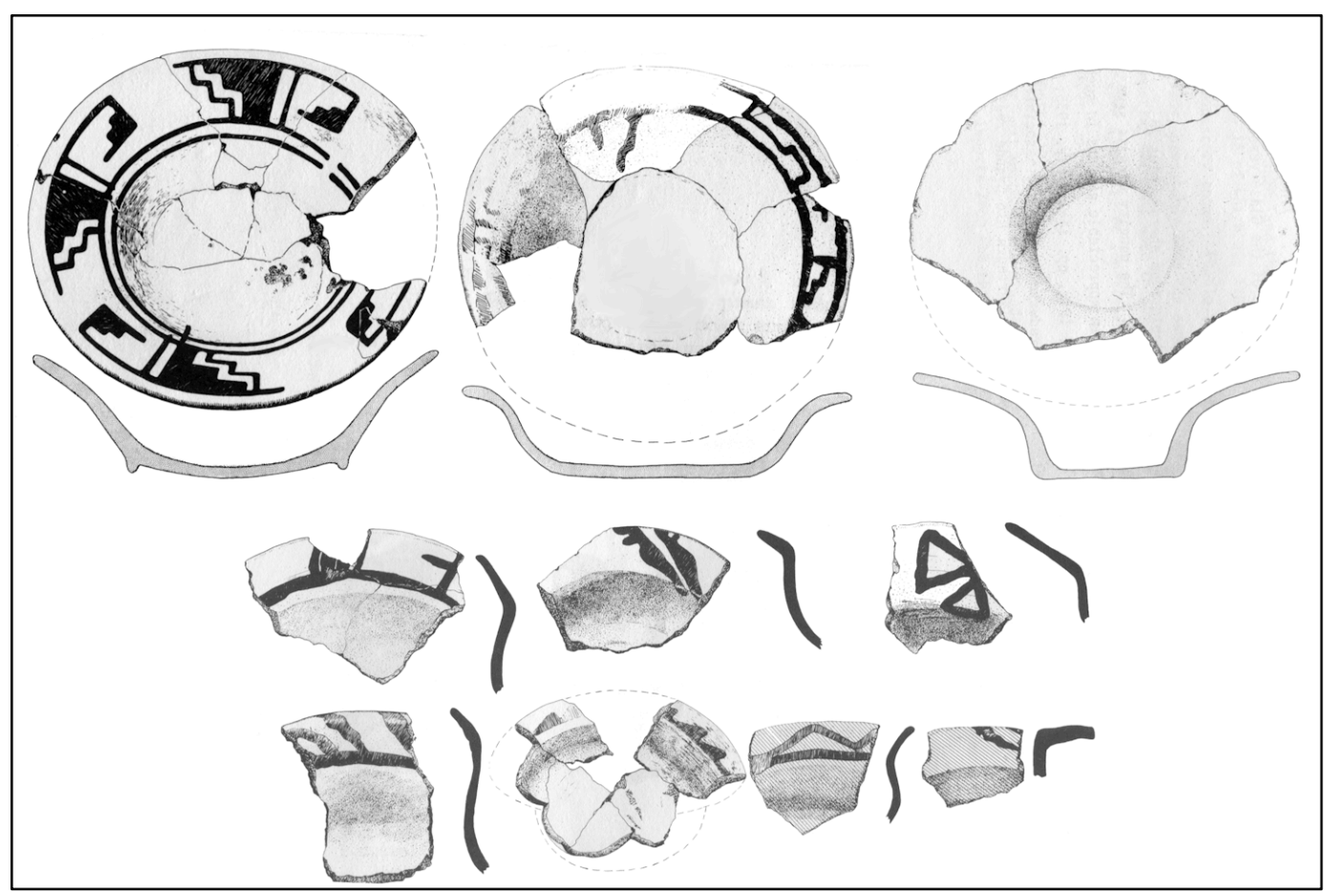

Figure 4: Seventeenth-century soup plates (top) and rim sherds (bottom) from northern New Mexico (after Lambert 1981:figs 3, 4, \& 6) 


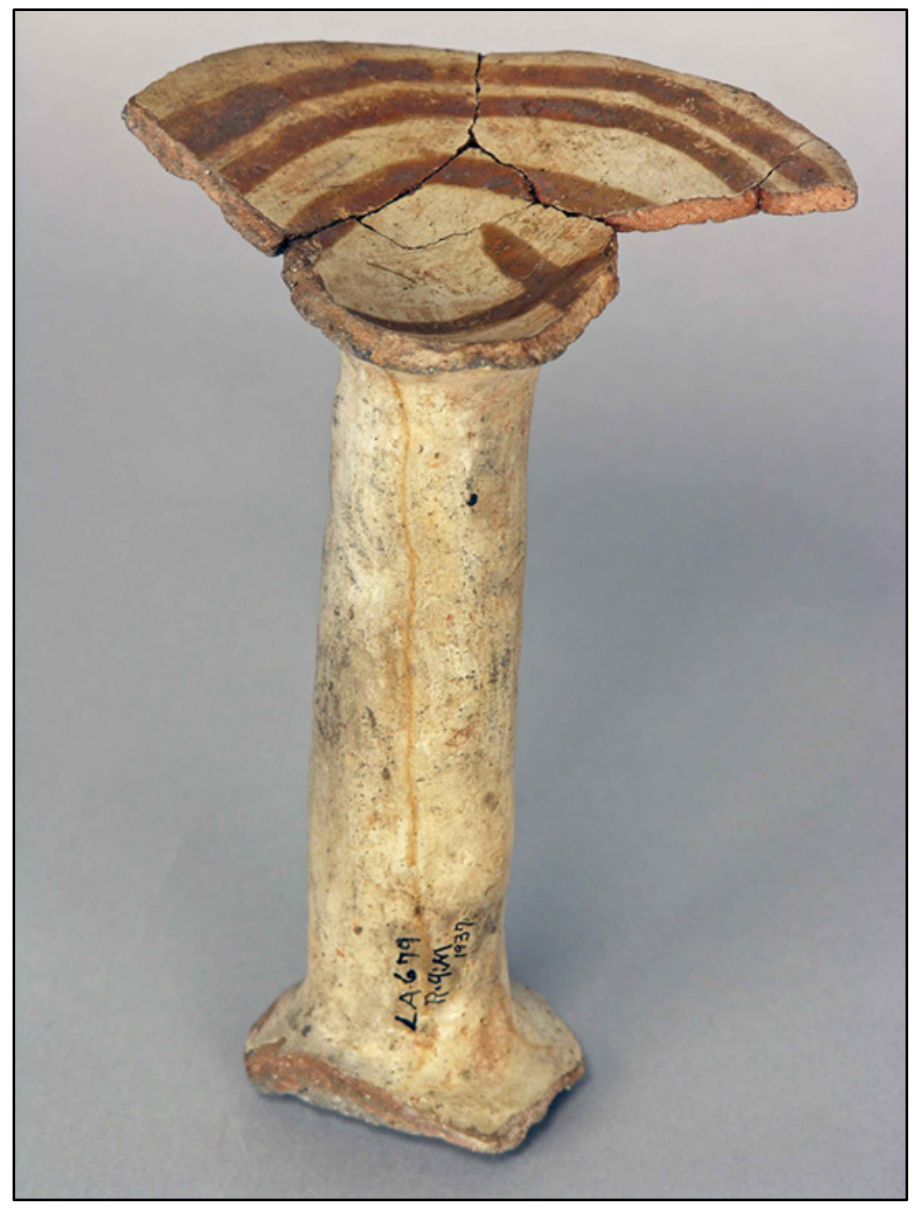

Figure 5: Jemez Black-on-white Chalice from Giusewa. Photo by David McNeece courtesy of the Museum of Indian Arts and Culture, Museum of New Mexico (18531/11) 